\title{
Discoveries of quartzite artefacts on the highest terrace: Early or Middle Pleistocene occupation of the Rhône Valley?
}

\author{
Marie-Hélène Moncel ${ }^{1, *}$, Simon Puaud ${ }^{1}$, Ludovic Mocochain ${ }^{2}$, \\ Evelyne Debard ${ }^{3} \&$ Bernard Gely $^{4}$
}

Artefacts in quartzite have been found in a unique topographical location on the highest terrace of the Rhône Valley in France. These discoveries offer new opportunities for dating early European occupations.

Keywords: Europe, France, Early Palaeolithic, quartzite, stone tools

Heavy-duty tools have been found on high river terraces in the south of Europe over the past decades (Bourdier 1958; Collina-Girard 1975; Tavoso 1978). Recently, beryllium-10 isotope and electron spin resonance dates yielded ages from one million years ago for terraces of the Eastern Pyrenees, highlighting the interest of such archaeological findings for dating and characterising the earliest occupation phases of Europe (Delmas et al. 2018).

The study area is located on the east flank of a limestone plateau above the middle part of the Rhône Valley, close to the terminal part of the Ardèche Gorges. The elevation is between 160 and $175 \mathrm{~m}$ asl (Figures $1-3)$. Seven large flakes $(0.15-0.20 \mathrm{~m}$ long) and one core in quartzite were found in the alluvial deposits (Figure 4). Scars are centripetal or unipolar. The thick platforms are cortical or flat. The core is bi-pyramidal with percussion impacts.

The artefacts were found in the Ardèche alluvial terraces. Previous studies show four levels of terraces (Labrousse 1977; Pascal et al. 1989), ranging from the present floodplain of the Ardèche River (level Fz) to the highest terrace where the artefacts were located (level Fv). A large plane surface corresponds to the Fv terrace and flanks the pediment.

The artefacts were found on a subhorizontal ledge partially cut by a palaeogully, which is extended by a present-day gully. The formation of this gully is probably polygenic. The upper part is totally dry and appears as a small infilled valley, while downstream it is steep-sided and crossed by episodic flows. Artefacts are not reworked, and show burial by colluviation and pedogenesis (slightly smoothed edges, thin and reddish glossy sheen without impact

1 CNRS, UMR 7194, National Museum of Natural History, Institut de Paléontologie Humaine, Paris 75005, France

298 Route du Mas, 38250 Lans-en-Vercors, France

3 Département des Sciences de la Terre, University Claude Bernard, Lyon 1, France

4 Service Régional de l'Archéologie, Auvergne-Rhône-Alpes, Quai Saint-Vincent, Lyon 69001, France

* Author for correspondence (Email: marie-helene.moncel@mnhn.fr) 


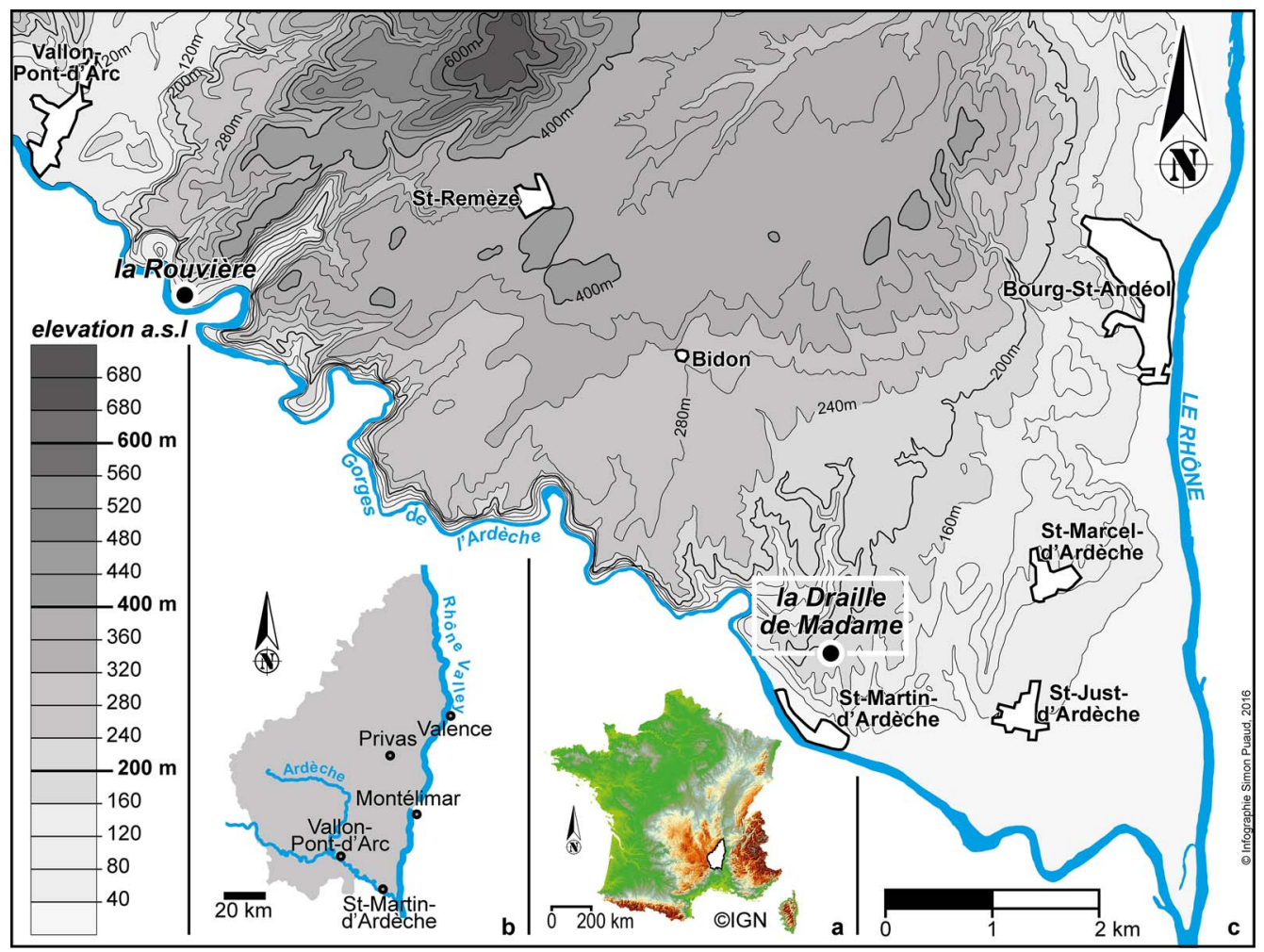

Figure 1. Map of the middle part of the Rhône Valley, showing the right (north) bank of the river; the site is located on the interfluve at 160-175m asl (figure by Simon Puaud).

features of high-mobility processes). Regionally, the Fv terrace corresponds to the Pliocene abandonment surface with an age of two million years (Clauzon 1982, 1996), which is correlated with the youngest fossiliferous level of Saint-Vallier (MNQ17 biozone) (Guérin et al. 2004). In the study area, the age of this surface was estimated between 1.94 and 1.77 million years by combined absolute dating and palaeomagnetism (Tassy et al. 2013).

\section{How to interpret the discovery of heavy-duty tools on this high terrace}

The lithic series is clearly flaked by humans. Their technological features are typical of early Lower Palaeolithic behaviours (Moncel \& Ashton 2018). No similar discoveries have been reported on younger alluvial formations in the same area despite systematic surveys over the past two decades. The stratigraphic position of these artefacts on the side of this high terrace shows that they could not have been introduced by natural processes. Our findings only concern a deposit corresponding to the remains of an alluvial formation dated to before 1.7 million years ago. Evidence of human occupations is later than the first downcutting phase of the palaeogully, which caused the erosion of the Fv terrace. Human occupation was probably contemporaneous with or later than the filling of the palaeogully, as downcutting would probably have destroyed the artefacts along with the Fv terrace. The age of the artefacts presented (C) Antiquity Publications Ltd, 2019 


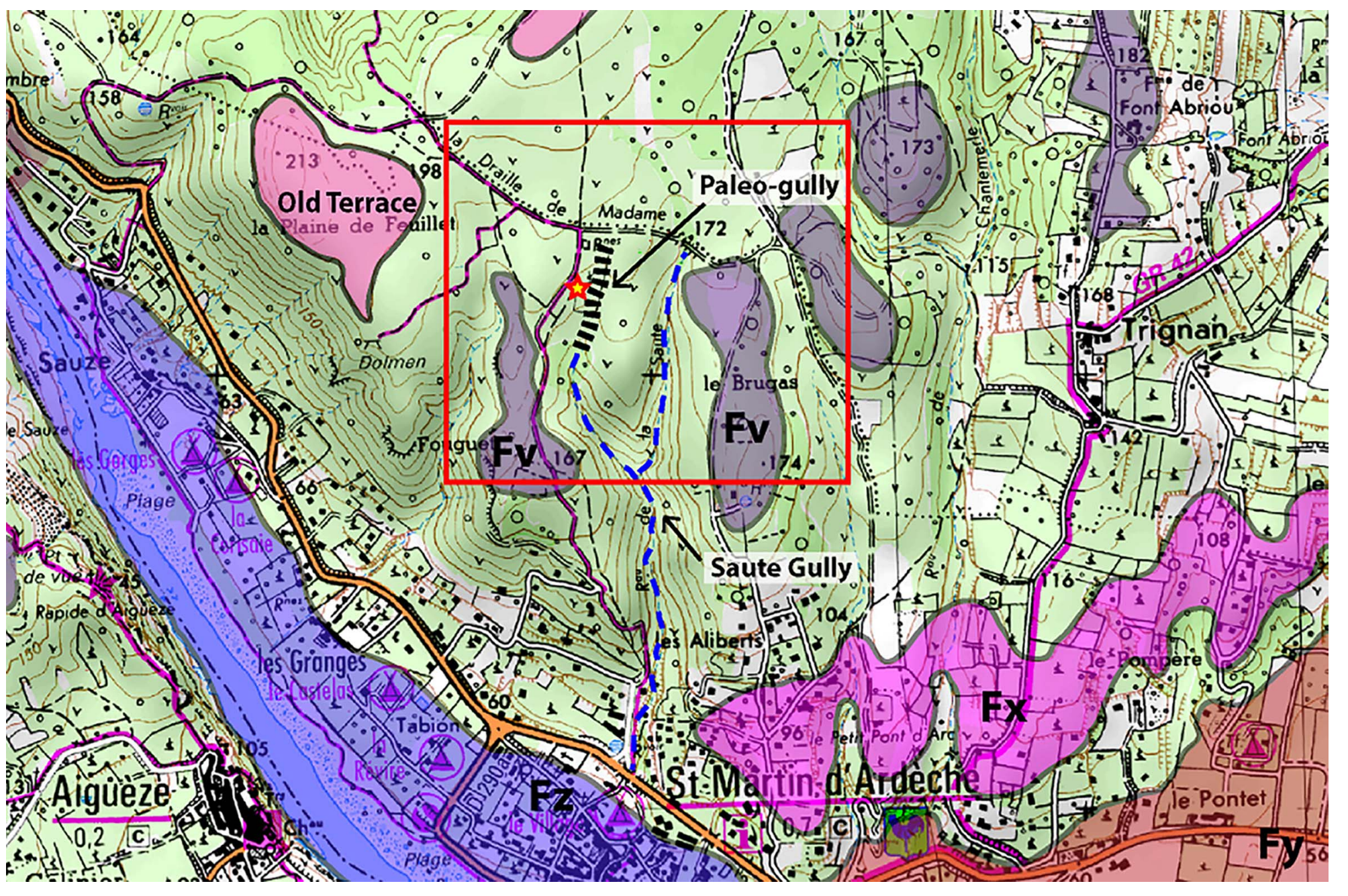

Figure 2. Detailed location of the Fv alluvial terrace; the star marks the location of artefacts (modified after Pascal et al. 1989). 


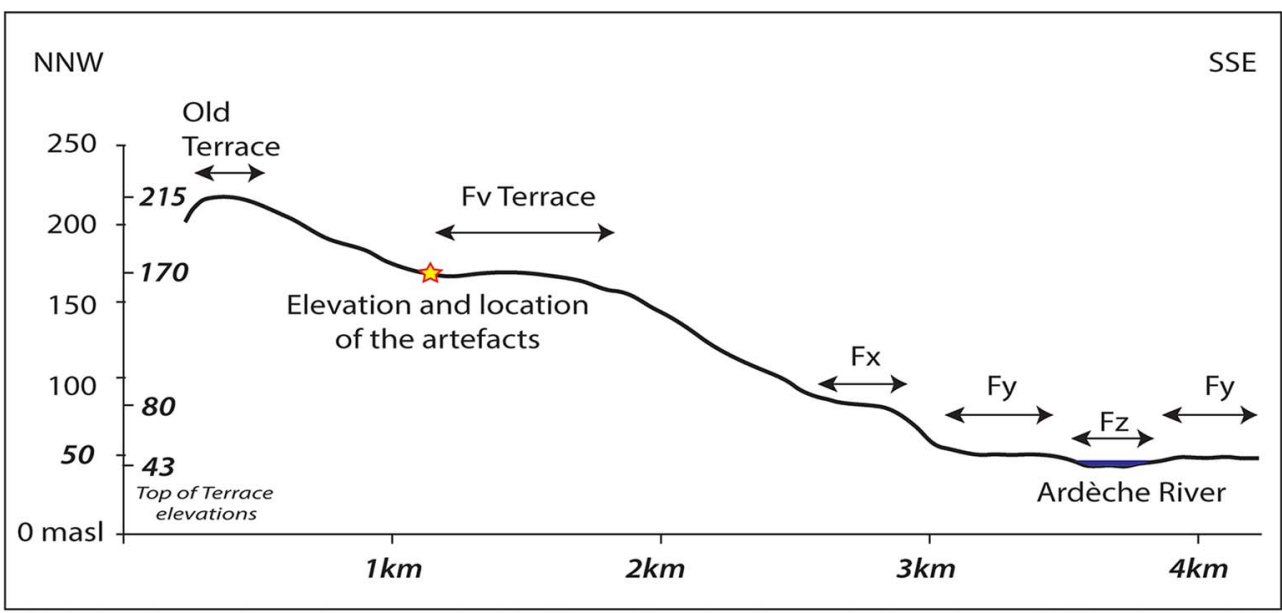

Figure 3. Transverse section through the terraces of the lower Ardeche River (star marks the location of site) (figure by Ludovic Mocochain).
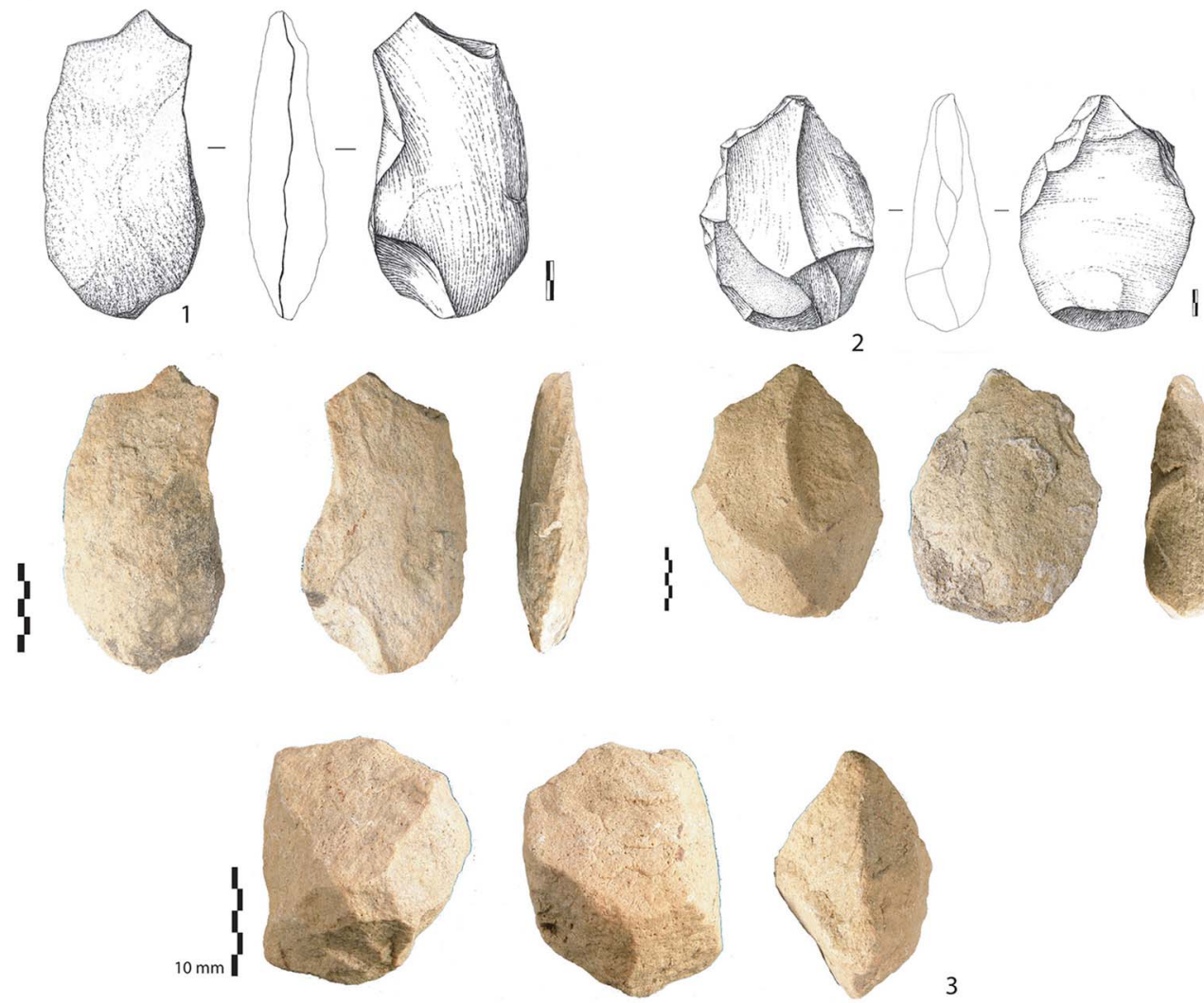

Figure 4. Quartzite large flakes and core (photographs by Marie-Hélène Moncel, illustrations by Angeliki Theodoropoulou).

(C) Antiquity Publications Ltd, 2019 
here is clearly not as early as the formation in which they were found, but nonetheless their location raises questions. They could attest to sporadic traces of early hominid passage from 1.7 million years ago in this part of France, just below an alluvial formation bordering a large plain.

The unique topographical location and the technological features of this discovery highlight the difficulties in interpreting isolated artefacts on high alluvial formations, but also open new avenues of research for dating early European occupations.

\section{Acknowledgements}

Surveys were supported by the French Ministry of Culture and the Service Regional de l'Archéologie, Auvergne-Rhône-Alpes.

\section{References}

Bourdier, F. 1958. Le Bassin du Rhône au Quaternaire: géologie et préhistoire. Paris: Éditions CNRS.

Clauzon, G. 1982. Le canyon messinien du Rhône; une preuve décisive du 'desiccated deep-basin model'. Bulletin Société Géolique France 24: 597-610. https://doi.org/10.2113/gssgfbull.S7-XXIV.3.597

- 1996. Limites de séquences et évolution géodynamique. Géomorphologie 2(1): 3-21.

Collina-Girard, J. 1975. Les industries archaïques sur galets des terrasses quaternaires de la Plaine du Roussillon (PO, France). Unpublished PhD dissertation, Université Aix-Marseille I.

Delmas, M., M. Calvet, T. Gunnell, P. Voinchet, C. Manel, R. Braucher, H. Tissoux, J.-J. Bahain, C. Perrenoud, T. SAOs \& ASTER Team. 2018. Terrestrial ${ }^{10} \mathrm{Be}$ and electron spin resonance dating of fluvial terraces quantifies Quaternary uplift gradients in the Eastern Pyrenees. Quaternary Sciences Review 193: 188-211.

https://doi.org/10.1016/j.quascirev.2018.06.001

GuÉRIN, C. et al. 2004. Le gisement pliocène supérieur de Saint-Vallier (Drôme, France): synthèse biostratigraphique et paléoécologique. Géobios 37: S349-60. https://doi.org/10.1016/S0016-6995(04)80023-8
Labrousse, B. 1977. Altérations des terrasses anciennes de l'Ardèche. Unpublished PhD dissertation, Université Aix Marseille I.

Moncel, M.-H. \& N. Ashton. 2018. From 800 to $500 \mathrm{ka}$ in Europe. The oldest evidence of Acheuleans in their technological, chronological and geographical framework, in R. Gallotti \& M. Mussi (ed.) The emergence of the Acheulean in East Africa: 215-35. Cham: Springer International. https://doi.org/10.1007/978-3-319-75985-2_11

Pascal, M., S. Elmi, R. Busnardo, D. Lafarge, G. Truc, M.-M. Valleron. 1989. Carte géologique de la France (1/50 000), feuille Bourg-Saint-Andéol (889). Orléans: Bureau de recherches géologiques et minières.

Tassy, A., L. Mocochain, O. Bellier, R. Braucher, J. Gattcceca \& D. Bourlès. 2013. Coupling cosmogenic dating and magnetostratigraphy to constrain the chronological evolution of peri-Mediterranean karsts during the Messinian and Pliocene: example of Ardèche Valley, southern France. Geomorphology 189: 81-92. https://doi.org/10.1016/j.geomorph.2013.01.019

TAvoso, A. 1978. Le Paléolithique inférieur et moyen du Haut Languedoc: gisements des terrasses alluviales du Tarn, du Dadou, de l'Agout, du Sor et $d u$ Fresquel (Études Quaternaires 4). Marseille: Université de Provence.

Received: 18 December 2018; Revised: 19 March 2019; Accepted: 4 February 2019

(C) Antiquity Publications Ltd, 2019 